\title{
Clinical profile and laboratory findings of patients with thrombocytopenia in hospital set up: A hospital based prospective study
}

\author{
Priyanka Agarwal ${ }^{1}$, *Dillip Kumar Dash ${ }^{1}$, Mrinal Sinha ${ }^{1}$, Mamta Kumari ${ }^{1}$, Mamta Devi Mohanty ${ }^{1}$, A S A \\ M Srikant ${ }^{1}$
}

Sri Lanka Journal of Child Health, 2021; 50(1): 94-102

\begin{abstract}
Introduction: Thrombocytopenia is commonly encountered in our routine clinical practice. Causes being numerous, it poses a challenge in evaluating and treating the patients.
\end{abstract}

Objectives: To determine the causes, clinical profile and outcome of thrombocytopenia in children aged 1 month to 14 years who were admitted in our set up.

Method: This was a prospective study done on 200 patients aged 1 month to 14 years with thrombocytopenia admitted to the Institute of Medical Sciences AND SUM Hospital, Bhubaneshwar, Odisha, India with various complaints, from 01-08-2017 TO 01-08-2019.

Results: Fifty six (28\%) children were in the 3-6 year age group. In $116(58 \%)$ children the thrombocytopenia was in the rainy season. Common causes of thrombocytopenia were dengue (18.5\%), sepsis $(16.5 \%)$ and scrub typhus (16\%). Petechiae was the commonest bleeding manifestation (62\%) followed by epistaxis (13.7\%). Out of 32 cases of scrub typhus 23 (71.8\%) had deranged liver function tests. Out of the 8 children that died, one had platelet count $\leq 10,000 / \mu \mathrm{L}$, one had platelet count $10,000-20,000 / \mu \mathrm{L}$ while 3 each had platelet counts in the range of $22,000-$ $50,000 / \mu \mathrm{L}$ and $>50,000 / \mu \mathrm{L}$ respectively

Conclusions: There was male predominance. The commonest age group was 3-6 years. Thrombocytopenia was more common during the rainy season. Common causes were dengue, septicaemia and scrub typhus. Common clinical

$\overline{{ }^{1} \text { Institute of Medical Sciences and SUM Hospital, }}$ India

*Correspondence: drdillipdash10.10@gmail.com

https://orcid.org/0000-0001-6161-2121

(Keceived on 11 April 2020: Accepted after revision on 22 May 2020)

The authors declare that there are no conflicts of interest

Personal funding was used for the project.

Open Access Article published under the Creative

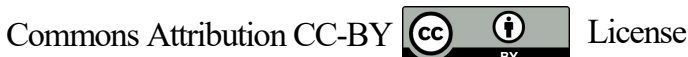

presentations were fever, organomegaly, generalised myalgia, lymphadenopathy and headache. Petechiae/Purpura was the most common bleeding manifestation. Mortality rate was $4 \%$.

DOI: http://dx.doi.org/10.4038/sljch.v50i1.9409

(Key words: Thrombocytopenia, septicaemia, dengue fever, malaria, bleeding manifestations)

\section{Introduction}

Thrombocytopenia is a common presentation of many febrile and a few non-febrile illnesses in children ${ }^{1}$. Thrombocytopenia denotes a platelet count lower than $150,000 / \mathrm{cu} \mathrm{mm}$ whilst severe thrombocytopenia denotes a platelet count lower than 50,000/cu mm. Pseudo-thrombocytopenia can occur due to use of excessive ethylene diamine tetra-acetic acid (EDTA) while sampling ${ }^{2}$. Basic mechanisms of thrombocytopenia are impaired platelet production, consumption and sequestration of platelets and a combination of the above two factors $^{2}$. Multiple mechanisms are involved in immune thrombocytopenia (ITP) and drug-induced thrombocytopenia ${ }^{3}$. Patients with acute febrile illness like dengue and malaria are often associated with thrombocytopenia ${ }^{4-8}$.

\section{Objectives}

- To determine the causes and clinical manifestations of thrombocytopenia in children aged 1 month to 14 years who were admitted in our set up.

- To determine the incidence of various types of thrombocytopenia (i.e. febrile, immune, non-immune)

\section{Method}

A hospital based observational study was conducted from 01-08-2017 to 01-08-2019 in the Department of Paediatrics, Institute of Medical Sciences (IMS) and SUM hospital Bhubaneshwar, Odisha, India. Children in the age group of 1 month to 14 years whose haemogram revealed a total platelet count $<150,000$ and who were admitted to the ward or intensive care unit were enrolled.

Sample size: 200 patients considering a confidence level of $98 \%$ and confidence interval of 4 the number of patients in our study to achieve 
statistical significance is 196. This was calculated by Survey System

(http://www.surveysystem.com/sscalc.htm\#one).

The Survey System ignores the population size when it is "large" or unknown". Hence a sample size of 200 was considered adequate for our study.

Inclusion criteria: Children aged 1 month to 14 years of age admitted in our hospital with a total platelet count less than $150,000 / \mathrm{mm}^{3}$.

Clinical data: Presenting symptoms were recorded as per Proforma. Date of onset of symptoms, duration of symptoms, history of drug intake, recent vaccination, family history of blood disorder, previous history of blood transfusion etc. were noted. A detailed examination of the child was done with special attention to the presence of any rash, mucosal bleed, hepatosplenomegaly, lymphadenopathy, sternal tenderness etc.

Sample collection and laboratory analysis: Two $\mathrm{ml}$ of blood was collected in EDTA vial through a clean venepuncture from children admitted in our hospital. Samples were sent immediately to the clinical laboratory. $\mathrm{CBC}$ was done using a 6 part auto-analyser XN-1000 series.

Ethical issues: Approval for the study was obtained from the IMS \& SUM Hospital ethics committee (ERC No. DMR/IMS$\mathrm{SH} / \mathrm{SOA} / 170065)$. Patients and/or parents were informed about the study in detail and written consent was taken for inclusion in study. Confidentiality was ensured and participants were informed about right to discontinue participation.

Statistical analysis: Quantitative data are presented using mean and standard deviation. Comparison among the study groups was done using unpaired ttest. Qualitative data are presented using frequency and percentages. Association among study groups is assessed using Fisher test, student t-test and ChiSquare test. 'p' value less than 0.05 is taken as significant. MS Excel, SPSS ver. 20 are used for statistical analysis. Graphical representation are done in MS Excel 2010.

\section{Results}

A total of 200 children were included in the study. There were $117(58.5 \%)$ males and 83 (41.5\%) females. The mean age of the children was $6.6 \pm$ 4.5 years. The distribution of children according to age is shown in Table 1.

The distribution of children according to season is shown in Table 2. It was observed that the thrombocytopenia was more common (58\%) during the rainy season.
Table 1: Age distribution of children

\begin{tabular}{|l|c|}
\hline \multicolumn{1}{|c|}{ Age in years } & $\mathbf{n}(\mathbf{0})$ \\
\hline$<1$ & $27(13.5)$ \\
\hline 1 to $<3$ & $35(17.5)$ \\
\hline 3 to $<6$ & $56(28.0)$ \\
\hline 6 to $<9$ & $45(22.5)$ \\
\hline 9 to 14 & $37(18.5)$ \\
\hline Total & $200(100.0)$ \\
\hline
\end{tabular}

Table 2: Distribution according to season

\begin{tabular}{|l|c|}
\hline \multicolumn{1}{|c|}{ Season } & $\mathbf{n}(\%)$ \\
\hline Winter & $48(24)$ \\
\hline Summer & $36(18)$ \\
\hline Rainy & $116(58)$ \\
\hline Total & $200(100)$ \\
\hline
\end{tabular}

The distribution of children according to fever is shown in Table 3. It was observed that the thrombocytopenia was more common $(83 \%)$ in patients with fever.

Table 3: Distribution according to fever

\begin{tabular}{|l|c|}
\hline \multicolumn{1}{|c|}{ Type } & n (\%) \\
\hline Febrile & $166(83)$ \\
\hline Afebrile & $34(17)$ \\
\hline Total & $200(100)$ \\
\hline
\end{tabular}

The distribution of children according to aetiology is shown in Table 4. It was observed that dengue was the most common (18.5\%) cause of thrombocytopenia closely followed by septicaemia (16.5\%) and scrub typhus (16.0\%).

Table 4: Distribution according to aetiology

\begin{tabular}{|c|c|}
\hline Aetiology & $\mathrm{n}(\%)$ \\
\hline Dengue & $37(18,5)$ \\
\hline Septicaemia & $33(16.5)$ \\
\hline Scrub typhus & $32(16.0)$ \\
\hline Enteric fever & $17(08.5)$ \\
\hline Leukaemia/Lymphoma & $15(07.5)$ \\
\hline $\begin{array}{l}\text { Immune thrombocytopenic } \\
\text { purpura }\end{array}$ & $11(05.5)$ \\
\hline Haemolytic uraemic syndrome & $09(04.5)$ \\
\hline Hypersplenism & $08(04.0)$ \\
\hline Meningitis & $08(04.0)$ \\
\hline Encephalitis & $06(03.0)$ \\
\hline SOJA & $06(03.0)$ \\
\hline Viral fever & $03(01.5)$ \\
\hline Aplastic anaemia & $03(01.5)$ \\
\hline Drug induced & $03(01.5)$ \\
\hline Malaria & $02(01.0)$ \\
\hline Megaloblastic anaemia & $02(01.0)$ \\
\hline Storage disorder & $02(01.0)$ \\
\hline Secondary HLH & $02(01.0)$ \\
\hline Urinary tract infection & $01(0.5)$ \\
\hline Total & $200(100)$ \\
\hline
\end{tabular}

SOJLA: Systemic onset Juvenile idiopathic arthritis, HLH: Haemophagocytic lymphohistiocytosis 
The distribution of children according to clinical presentation is shown in Table 5. Common clinical presentations were fever $(83 \%)$, organomegaly $(72.5 \%)$, generalised myalgia/headache $(66 \%)$ and lymphadenopathy $(52.5 \%)$

Table 5: Distribution according to presentation

\begin{tabular}{|l|c|}
\hline \multicolumn{1}{|c|}{ Clinical presentation } & $\mathbf{n}(\mathbf{\%})$ \\
\hline Fever & $166(83.0)$ \\
\hline Organomegaly & $145(72.5)$ \\
\hline Generalised myalgia/headache & $132(66.0)$ \\
\hline Lymphadenopathy & $105(52.5)$ \\
\hline Oedema & $98(49.0)$ \\
\hline Vomiting & $90(45.0)$ \\
\hline Abdominal pain & $86(43.0)$ \\
\hline Jaundice & $80(40.0)$ \\
\hline Bleeding tendency & $58(29.0)$ \\
\hline Rash & $55(27.5)$ \\
\hline Sore throat & $12(06.0)$ \\
\hline Altered sensorium & $11(05.5)$ \\
\hline Seizure & $09(04.5)$ \\
\hline Joint pain & $08(04.0)$ \\
\hline
\end{tabular}

Fifty eight (29\%) children had bleeding manifestations. Distribution of children according to the site of bleeding is shown in Table 6 . Petechiae/Purpura was the most common bleeding manifestation $(62 \%)$

The distribution of children according to platelet count is shown in Table 7.
Table 6: Distribution of children according to site of bleeding manifestation $(n=58)$

\begin{tabular}{|l|c|}
\hline Site of bleeding manifestation & n $\mathbf{~ ( \% )}$ \\
\hline Petechiae/Purpura & $36(62.0)$ \\
\hline Haematuria & $10(17.0)$ \\
\hline Epistaxis & $08(13.7)$ \\
\hline Gum bleed & $08(13.7)$ \\
\hline Melaena & $04(06.0)$ \\
\hline Haematemesis & $02(03.0)$ \\
\hline
\end{tabular}

Table 7: Distribution according to platelet count

\begin{tabular}{|l|c|}
\hline \multicolumn{1}{|c|}{ Platelet count } & n $(\%)$ \\
\hline$\leq 10,000 / \mu \mathrm{L}$ & $12(06.0)$ \\
\hline 10,000 to $<20,000 / \mu \mathrm{L}$ & $14(07.0)$ \\
\hline 20,000 to $50,000 / \mu \mathrm{L}$ & $53(26.5)$ \\
\hline$>50,000 / \mu \mathrm{L}$ & $121(60.5)$ \\
\hline Total & $200(100)$ \\
\hline
\end{tabular}

The association of platelet count with socioeconomic status is shown in Table 8 . Out of the 200 children $89(44.5 \%)$ belonged to the low socioeconomic group.

The association of bleeding manifestations and platelet count is shown in Table 9.

The association of bleeding manifestations and aetiology is shown in Table 10.

The association of aetiology and platelet count is shown in Table 11.

Table 8: Association of platelet count with socioeconomic status

\begin{tabular}{|c|c|c|c|c|c|c|}
\hline $\begin{array}{c}\text { Socioeconomic } \\
\text { status }\end{array}$ & $<10,000 / \mu \mathrm{L}$ & $\begin{array}{c}10,000 \text { to } \\
<20,000 / \mu \mathrm{L}\end{array}$ & $\begin{array}{r}20,000 \text { to } \\
50,000 / \mu \mathrm{L}\end{array}$ & $>50,000 / \mu \mathrm{L}$ & Total & $\%$ \\
\hline Low & 5 & 6 & 18 & 60 & 89 & 44.5 \\
\hline Medium & 4 & 5 & 11 & 33 & 53 & 36.5 \\
\hline High & 3 & 3 & 24 & 28 & 58 & 29.0 \\
\hline Total & 12 & 14 & 53 & 121 & 200 & 100 \\
\hline
\end{tabular}

Table 9: Association of bleeding manifestations and platelet count

\begin{tabular}{|l|c|c|c|}
\hline \multicolumn{1}{|c|}{ Platelet count $(\boldsymbol{\mu} \mathbf{L})$} & Total & \multicolumn{2}{c|}{ Bleeding manifestations (n=58) } \\
\cline { 3 - 4 } & & 04 & $\%$ \\
\hline$<10,000$ & 12 & 04 & 33.3 \\
\hline 10,000 to $<20,000$ & 14 & 07 & 28.5 \\
\hline 20,000 to 50,000 & 53 & 43 & 13.2 \\
\hline$>50,000$ & 121 & 58 & 35.5 \\
\hline Total & 200 & & 29.0 \\
\hline
\end{tabular}


Table 10: Association of bleeding manifestations and aetiology

\begin{tabular}{|l|c|c|c|}
\hline \multicolumn{1}{|c|}{ Aetiology } & Total & \multicolumn{2}{c|}{ Bleeding manifestations (n=58) } \\
\cline { 3 - 4 } & & $\mathrm{n}$ & $\mathbf{5}$ \\
\hline Dengue & 37 & 10 & 27.0 \\
\hline Septicaemia & 33 & 13 & 39.3 \\
\hline Scrub typhus & 32 & 04 & 12.5 \\
\hline Enteric fever & 17 & 0 & 0 \\
\hline Leukaemia/Lymphoma & 15 & 10 & 66.0 \\
\hline Immune thrombocytopenic purpura & 11 & 11 & 100.0 \\
\hline Haemolytic uraemic syndrome & 09 & 05 & 55.5 \\
\hline Hypersplenism & 08 & 0 & 0 \\
\hline Meningitis & 08 & 0 & 0 \\
\hline Encephalitis & 06 & 01 & 16.6 \\
\hline SOJIA & 06 & 0 & 0 \\
\hline Viral fever & 03 & 0 & 0 \\
\hline Aplastic anaemia & 03 & 03 & 100.0 \\
\hline Drug induced & 03 & 0 & 0 \\
\hline Malaria & 02 & 0 & 0 \\
\hline Megaloblastic anaemia & 02 & 0 & 0 \\
\hline Storage disorder & 02 & 01 & 50.0 \\
\hline Secondary HLH & 02 & 0 & 0 \\
\hline Urinary tract infection & 01 & 58 & 29.0 \\
\hline Total & 200 & 0 & \\
\hline SOJA: Systemic ons & & 0 & 0 \\
\hline
\end{tabular}

SOJIA: Systemic onset Juvenile idiopathic arthritis, HLH: Haemophagocytic lymphohistiocytosis

Table 11: Association of aetiology and platelet count

\begin{tabular}{|c|c|c|c|c|c|}
\hline \multirow{2}{*}{ Aetiology } & \multicolumn{4}{|c|}{ Platelet count $(/ \mu \mathrm{L})$} & \multirow[t]{2}{*}{ Total } \\
\hline & $<\mathbf{1 0 , 0 0 0 / \mu \mathrm { L }}$ & $\begin{array}{c}10,000 \text { to } \\
<20,000 / \mu \mathrm{L}\end{array}$ & $\begin{array}{c}20,000 \text { to } \\
50,000 / \mu \mathrm{L}\end{array}$ & $>50,000 / \mu \mathrm{L}$ & \\
\hline Dengue & 03 & 02 & 16 & 16 & 37 \\
\hline Septicaemia & 05 & 03 & 10 & 15 & 33 \\
\hline Scrub typhus & 0 & 02 & 10 & 20 & 32 \\
\hline Enteric fever & 0 & 0 & 01 & 16 & 17 \\
\hline Leukaemia/Lymphoma & 01 & 02 & 03 & 09 & 15 \\
\hline Immune thrombocytopenic purpura & 02 & 03 & 03 & 03 & 11 \\
\hline Haemolytic uraemic syndrome & 0 & 0 & 0 & 09 & 09 \\
\hline Hypersplenism & 0 & 01 & 01 & 06 & 08 \\
\hline Meningitis & 0 & 0 & 0 & 08 & 08 \\
\hline Encephalitis & 0 & 0 & 0 & 06 & 06 \\
\hline SOJIA & 0 & 0 & 05 & 01 & 06 \\
\hline Viral fever & 0 & 0 & 0 & 03 & 03 \\
\hline Aplastic anaemia & 0 & 0 & 0 & 03 & 03 \\
\hline Drug induced & 0 & 0 & 03 & 0 & 03 \\
\hline Malaria & 0 & 0 & 0 & 02 & 02 \\
\hline Megaloblastic anaemia & 0 & 0 & 01 & 01 & 02 \\
\hline Storage disorder & 0 & 0 & 0 & 02 & 02 \\
\hline Secondary HLH & 01 & 01 & 0 & 0 & 02 \\
\hline Urinary tract infection & 0 & 0 & 0 & 01 & 01 \\
\hline Total & 12 & 14 & 53 & 121 & 200 \\
\hline
\end{tabular}

SOJIA: Systemic onset Juvenile idiopathic arthritis, HLH: Haemophagocytic lymphohistiocytosis

The association of thrombocytopenia with deranged liver function tests (LFTs) is shown in Table 12. All patients with total bilirubin level $>2 \mathrm{mg} / \mathrm{dl}$ and alanine transaminase level more than
2 fold rise of upper limit of normal for age were considered to have deranged liver function tests. In our study out of 32 cases of scrub typhus 23 (71.8\%) had deranged LFTs. 
Table 12: Association of thrombocytopenia with deranged liver function tests

\begin{tabular}{|l|c|c|c|}
\hline \multicolumn{1}{|c|}{ Aetiology } & AST/ALT & Serum bilirubin & Total \\
\hline Dengue & 06 & 02 & $06(16.2 \%)$ \\
\hline Septicaemia & 14 & 14 & $14(42.4 \%)$ \\
\hline Scrub typhus & 23 & 05 & $23(71.8 \%)$ \\
\hline Enteric fever & 04 & 0 & $04(23.5 \%)$ \\
\hline Leukaemia/Lymphoma & 03 & 04 & $04(26.6 \%)$ \\
\hline Immune thrombocytopenic purpura & 0 & 0 & 0 \\
\hline Haemolytic uraemic syndrome & 02 & 01 & $03(22.3 \%)$ \\
\hline Hypersplenism & 01 & 0 & $01(12.5 \%)$ \\
\hline Meningitis & 0 & 0 & 0 \\
\hline Encephalitis & 0 & 01 & $01(16.6 \%)$ \\
\hline SOJIA & 04 & 01 & $04(66.6 \%)$ \\
\hline Viral fever & 0 & 0 & 0 \\
\hline Aplastic anaemia & 03 & 01 & $03(100 \%)$ \\
\hline Drug induced & 01 & 0 & $01(33.3 \%)$ \\
\hline Malaria & 02 & 02 & $02(100 \%)$ \\
\hline Megaloblastic anaemia & 0 & 0 & 0 \\
\hline Storage disorder & 02 & 01 & $02(100 \%)$ \\
\hline Secondary HLH & 02 & 02 & $02(100 \%)$ \\
\hline Urinary tract infection & 0 & 0 & 0 \\
\hline
\end{tabular}

SOJIA: Systemic onset Juvenile idiopathic arthritis, HLH: Haemophagocytic lymphohistiocytosis

The association of thrombocytopenia with deranged renal function tests (RFTs) is shown in Table 13. Patients with serum creatinine $>0.5 \mathrm{mg} / \mathrm{dl}$, or more than twice the upper limit of normal for age or 2 fold increase in baseline creatinine value were considered to have deranged renal function tests. In our study all the children suffering from HUS and secondary HLH had deranged RFTs

Table 13: Association of thrombocytopenia with deranged renal function tests

\begin{tabular}{|l|c|c|}
\hline \multicolumn{1}{|c|}{ Aetiology } & Creatinine & Total \\
\hline Dengue & 04 & $04(10.8 \%)$ \\
\hline Septicaemia & 15 & $15(45.5 \%)$ \\
\hline Scrub typhus & 02 & $02(06.3 \%)$ \\
\hline Enteric fever & 0 & 0 \\
\hline Leukaemia/Lymphoma & 03 & $03(20.0 \%)$ \\
\hline Immune thrombocytopenic purpura & 0 & 0 \\
\hline Haemolytic uraemic syndrome & 09 & $09(100 \%)$ \\
\hline Hypersplenism & 01 & $01(12.5 \%)$ \\
\hline Meningitis & 0 & 0 \\
\hline Encephalitis & 01 & $01(16.6 \%)$ \\
\hline SOJIA & 0 & 0 \\
\hline Viral fever & 0 & 0 \\
\hline Aplastic anaemia & 0 & 0 \\
\hline Drug induced & 01 & $01(33.3 \%)$ \\
\hline Malaria & 01 & $01(50.0 \%)$ \\
\hline Megaloblastic anaemia & 0 & 0 \\
\hline Storage disorder & 01 & $01(50.0 \%)$ \\
\hline Secondary HLH & 02 & $02(100 \%)$ \\
\hline Urinary tract infection & 01 & $01(100 \%)$ \\
\hline
\end{tabular}

SOJIA: Systemic onset Juvenile idiopathic arthritis, HLH: Haemophagocytic lymphohistiocytosis

In our study, $192(96 \%)$ children had complete recovery while $8(4 \%)$ children died. The association between aetiology and mortality is shown in Table 14. It was observed that out of the 8 children that died, 3 had septicaemia, 1 had dengue, 2 had leukaemia and 2 had HLH.

The association between the platelet count and mortality is shown in Table 15. 
Table 14: Association between aetiology and mortality

\begin{tabular}{|l|c|c|c|}
\hline \multirow{2}{*}{ Aetiology } & \multicolumn{2}{c|}{ Total } \\
\cline { 2 - 3 } & Survived & Died & 37 \\
\hline Dengue & 36 & 01 & 33 \\
\hline Septicaemia & 30 & 03 & 32 \\
\hline Scrub typhus & 32 & 0 & 17 \\
\hline Enteric fever & 17 & 02 & 15 \\
\hline Leukaemia/Lymphoma & 13 & 0 & 11 \\
\hline Immune thrombocytopenic purpura & 11 & 0 & 09 \\
\hline Haemolytic uraemic syndrome & 09 & 0 & 08 \\
\hline Hypersplenism & 08 & 0 & 08 \\
\hline Meningitis & 08 & 0 & 06 \\
\hline Encephalitis & 06 & 0 & 06 \\
\hline SOJIA & 06 & 0 & 03 \\
\hline Viral fever & 03 & 0 & 03 \\
\hline Aplastic anaemia & 03 & 0 & 03 \\
\hline Drug induced & 03 & 0 & 02 \\
\hline Malaria & 02 & 0 & 02 \\
\hline Megaloblastic anaemia & 02 & 0 & 02 \\
\hline Storage disorder & 02 & 02 & 02 \\
\hline Secondary HLH & 0 & 0 & 01 \\
\hline Urinary tract infection & 01 & 08 & 200 \\
\hline Total & 192 & 0 & \\
\hline SOJA: Systemic & 03 & \\
\hline
\end{tabular}

SOJIA: Systemic onset Juvenile idiopathic arthritis, HLH: Haemophagocytic lymphohistiocytosis

Table 15: Association between platelet count and mortality

\begin{tabular}{|l|c|c|c|}
\hline \multirow{2}{*}{ Platelet count } & Total & n & Mortality $(\boldsymbol{n}=\boldsymbol{8})$ \\
\cline { 3 - 4 } & & 01 & 8.3 \\
\hline$<10,000$ & 12 & 01 & 7.1 \\
\hline 10,000 to $<20,000$ & 14 & 03 & 5.6 \\
\hline 20,000 to 50,000 & 53 & 03 & 2.4 \\
\hline$>50,000$ & 121 & 08 & 4.0 \\
\hline Total & 200 & & \\
\hline
\end{tabular}

\section{Discussion}

Thrombocytopenia is defined as a platelet count less than $150,000 / \mathrm{cu} \mathrm{mm}^{10}$. Xu Y, et al ${ }^{11}$ observed that the commonest age group of children having thrombocytopenia $(18.8 \%)$ was 1 to 3 years but in our study the commonest age group of children having thrombocytopenia (28\%) was 3 to 6 years. This difference in age groups may be due to more children in the 3-6 year age group being exposed to infections in our setup. Ahmed S, et al ${ }^{12}$ and Shah GS. et $a l^{13}$ observed male predominance. This was similar to our study where $58.5 \%$ were males. In the present study $58 \%$ cases were reported during the rainy season whereas Kumar $\mathrm{P}$, et $a l^{14}$ reported the majority of cases during the summer season. This may be because scrub typhus, a common aetiology in our study, is more prevalent during the rainy season due to increasing humidity which favours hatching of the mite egg into chigger which is responsible for disease transmission.

Isaac $\mathrm{R}$, et $a l^{15}$ found that $83 \%$ of cases with thrombocytopenia were infectious in aetiology and associated with fever. Patil $\mathrm{P}$, et $a l^{16}$, Rekha MC, et $a l^{17}$ and Anand $\mathrm{N}$, et $a l^{18}$ found that dengue fever and enteric fever were the common aetiologies. Raikar SR, et $a l^{19}$ and Bhalara SK, et $a l^{20}$ found that dengue fever was the commonest aetiology. Suresh $\mathrm{P}$, et $a l^{21}$, Kumar $\mathrm{P}$, et $a l^{14}$ and Gandhi AA, et $a l^{22}$ found dengue and malaria to be common aetiologies. In the present study $18.5 \%$ were due to dengue, $16 \%$ to scrub typhus and $8.5 \%$ to enteric fever, malaria contributing to only $1 \%$ of cases. The low contribution of malaria in our study may be due to the Durgama Anchalare Malaria Nirakaram (DAMAN) programme in our state.

Shah GS. et $a l^{13}$ found hepatomegaly in $75 \%$, splenomegaly in $25 \%$ and bleeding tendency in $50 \%$ of children with thrombocytopenia. Yaramis A, et $a l^{23}$ found hepatomegaly in $40 \%$, splenomegaly in $20 \%$ and altered sensorium in $6 \%$ of thrombocytopenic children. Ahmed $\mathrm{S}$, et $a l^{12}$ found pallor in $67 \%$, hepatomegaly in $37 \%$ and splenomegaly in $6 \%$ of children with thrombocytopenia whilst Sajid A, et $a l^{24}$ found splenomegaly in $94 \%$, pallor in $65 \%$ and hepatomegaly in $64 \%$ of children with thrombocytopenia. Kumar P, et $a l^{14}$ and Ahmed S, et $a l^{12}$ found that gastro-intestinal (GI) symptoms 
were the commonest followed by headache and bleeding. Yaramis A, et $a l^{23}$, Sajid A, et $a l^{24}$ and Chitu $\mathrm{CH}$ et $a l^{25}$ also found GI symptoms in more than two third cases. Shah GS. et al ${ }^{13}$ and Anand N, et $a l^{18}$ found headache was more common than GI symptoms in children with thrombocytopenia. In the present study, on admission, $83 \%$ children were febrile, $72.5 \%$ had organomegaly $(18 \%$ splenomegaly, 52\% hepatomegaly and $30 \%$ hepatosplenomegaly), $\quad 52.5 \% \quad$ had lymphadenopathy, $45 \%$ had vomiting, and $43 \%$ had abdominal pain.

In the present study 58 (29\%) children had bleeding manifestations. Petechiae were found in $62 \%$, gum bleeding in $13.7 \%$ and haematemesis in $3 \%$. Similar findings were noted by Nair PS, et $a l^{26}$ and Saini KC, et $a l^{27}$. Ayub $\mathrm{M}$, et $a l^{28}$ found severe thrombocytopenia $(<10,000)$ in $60 \%$ children, moderate thrombocytopenia $(10,000-50,000)$ in $20 \%$ and mild thrombocytopenia $(>50,000)$ in $20 \%$. Bhalara SK, et al ${ }^{20}$ found severe thrombocytopenia in $50 \%$, moderate thrombocytopenia in $29 \%$ and mild thrombocytopenia in $21 \%$ children. Palange $\mathrm{PB}$, et $a \mathrm{l}^{29}$ found severe thrombocytopenia in $60 \%$, moderate thrombocytopenia in $27 \%$ and mild thrombocytopenia in $13 \%$. Mohan $\mathrm{K}$, et $a l^{30}$ found mild thrombocytopenia in $48 \%$, moderate thrombocytopenia in $35 \%$ and severe thrombocytopenia in $17 \%$ of children. Shah GS. et $a l^{13}$ found mild thrombocytopenia in 54\%, moderate thrombocytopenia in $40 \%$ and severe thrombocytopenia in $16 \%$ of children. Sajid A, et $a l^{24}$ found moderate thrombocytopenia in $68 \%$, mild thrombocytopenia in $21 \%$ and severe thrombocytopenia in $11 \%$. In the present study 121 $(60.5 \%)$ children had platelet count of $>50,000 / \mu \mathrm{L}$ whilst $12(6 \%)$ children had platelet count of $\leq 10,000 / \mu \mathrm{L}$.

Studies by Bhalara SK, et $a l^{20}$ and Patil $\mathrm{P}$, et $a l^{16}$ showed that bleeding manifestations were more common with platelet counts less than 50,000 cells/cu mm. In contrast, studies by Palange PB, et $a l^{29}$, Mohan K, et $a l^{30}$, Shah GS. et $a l^{13}$, Anand N, et $a l^{18}$ and Raikar SR, et $a l^{19}$ revealed that there was no relation between platelet count and bleeding manifestations and according to them it only depends upon the severity of the disease. In our study bleeding manifestations were seen in 35.5\% children having total platelet count more than 50,000 , particularly those suffering from infectious disease. Bleeding in these children (particularly in severe sepsis) was not directly associated with the degree of thrombocytopenia but with concomitant involvement of other organ leading to multi-organ dysfunction. Out of the 8 children that died, one had platelet count $\leq 10,000 / \mu \mathrm{L}$, one had platelet count $10,000-20,000 / \mu \mathrm{L}$ while 3 each had platelet counts in the range of $22,000-50,000 / \mu \mathrm{L}$ and $>50,000 / \mu \mathrm{L}$ respectively

In this study $89(44.5 \%)$ belonged to low socioeconomic status group. There were no other studies relating platelet counts to socioeconomic status. In our study, out of 32 cases of scrub typhus $23(71.8 \%)$ had deranged LFT. Similarly, 42.4\% and $16.2 \%$ of patients with sepsis and dengue had deranged LFT. Similar findings were seen in a study by Gondhali MP, et al. ${ }^{7}$ Of the 200 children included in the study $8(4 \%)$ died. Of the eight 3 children had septicaemia, one child had dengue, 2 had leukaemia and 2 had haemophagocytic lymphohistiocytosis (HLH). Palange $\mathrm{PB}$, et $a l^{29}$, Mohan K, et $a l^{30}$, Shah GS. et $a l^{13}$, Anand $\mathrm{N}$, et $a l^{18}$ and Raikar SR, et $a l^{19}$ revealed that there was no relationship between platelet count and mortality and according to them the mortality depends only on the severity of the disease and the presence of other co-morbid conditions.

\section{Conclusions}

There was male predominance. The commonest age group was 3-6 years. Thrombocytopenia was more common during the rainy season. Common causes were dengue, septicaemia and scrub typhus. Common clinical presentations were fever, organomegaly, generalised myalgia/headache and lymphadenopathy. Petechiae/Purpura was the most common bleeding manifestation. The mortality rate was $4 \%$.

\section{References}

1. Field LS, Kamet D. Fever. In: Kingman RM, Stanton BF, St Game III JW, Schurz. Nelson Textbook of Paediatrics. 20th ed. Elsevier; Philadelphia; 2016.

2. Handbook IMCI - Integrated Management of Childhood Illness. World Health Organization.2005; 32.

https://doi.org/10.1080/20786204.2005.10 873272

3. Scott JP. Platelet and blood vessel disorders. In: Kingman RM, Stanton BF, St Game III JW, Schurz. Nelson Textbook of Paediatrics. 20th ed. Elsevier; Philadelphia; 2016.

4. Rodriguez-Morales AJ, Sanchez E, Vargas M, Piccolo C, Colina R, Arria M. Anaemia and thrombocytopenia in children with Plasmodium vivax malaria. Journal of Tropical Pediatrics 2006; 52(1): 49-51. https://doi.org/10.1093/tropej/fmi069 PMid: 15980019

5. Cao XT, Ngo TN, Wills B, Kneen R, Nguyen TT, Ta TT, et al. Evaluation of the 
World Health Organization standard tourniquet test in the diagnosis of dengue infection in Vietnam. Tropical Medicine and International Health 2002; 7(2):125-132. https://doi.org/10.1046/j.13653156.2002.0 0841.x

PMid: 11841702

6. Aggarwal A, Chandra J, Aneja S, Patwari AK, Dutta AK. An epidemic of dengue haemorrhagic fever and dengue shock syndrome in children in Delhi. Indian Pediatrics 1998; 35: 727-32.

7. Gondhali MP, Vethekar M, Bhangale D, Choudhary K, Choudhary M, Patrike G, et al. Clinical assessment of fever with thrombocytopenia - A prospective study, International Journal of Medical Research \& Health Sciences 2016; 5(1):258-77.

8. Kalayanarooj S, Vaughn DW, Nimmannitya S, Green S, Suntayakorn S, Kunentrasa N, et al. Early clinical and laboratory indicators of acut dengue illness. Journal of Infectious Diseases 1997; 176(2): 313-21. https://doi.org/10.1086/514047

PMid: 9237695

9. Jaykaran, Saxena D, Yadav P, Kantharia ND. Negative studies published in medical journals of India do not give sufficient information regarding power/sample size calculation and confidence interval. Journal of Postgraduate Medicine 2011; 57(2):1767.

https://doi.org/10.4103/0022-3859.81861

PMid: 21654149

10. Comprehensive Guidelines for Prevention and Control of Dengue and Dengue Haemorrhagic Fever. World Health Oraganisation. 2011.

11. Xu Y, Jin D, Tong W, Duan Y. Aetiology and prognosis of thrombocytopenia in children: a case analysis in 683 children within 10 years of paediatric intensive care unit. Zhonghua Wei Zhong Bing Ji Jiu Yi Xиe. 2018; 30(10):968-72.

12. Ahmed S, Arif F, Yahya Y, Rehman A, Abbas K, Ashraf S, et al. Dengue fever outbreak in Karachi .A study of profile and outcome of children under 15 years of age. Journal of the Pakistan Medical Association 2008; 58(1):4-8.

13. Shah GS, Islam S, Das BK. Clinical and laboratory profile of dengue infection in children. Kathmandu University Medical Journal 2006; 4(13):40-3.
14. Kumar P, Chandhra K. A clinical study of febrile thrombocytopenia: A hospital-based retrospective study. Indian Journal of Clinical Practice 2014; 24(10): 952-7.

15. Isaac R, Varghese GM, Mathai EJM, Joseph I. Scrub typhus: prevalence and diagnostic issues in rural Southern India. Clinical Infectious Diseases 2004; 39(9):1395-6. https://doi.org/10.1086/424748 PMid: 15494919

16. Patil P, Solanke P, Harshe G. To study clinical evaluation and outcome of patients with febrile thrombocytopenia. International Journal of Scientific and Research Publications 2014; 4(10):1-3.

17. Rekha MC, Sumangala B, Ishwarya B. Clinical study of fever with thrombocytopenia. Journal of Evolution of Medical and Dental Sciences 2014; 3(51):11983-90. https://doi.org/10.14260/jemds/2014/3581

18. Anand N, Talib SH, Bhushan P, Piyush P, Aniket K. Clinical outcomes of patients presenting as fever with thrombocytopenia in Marathwada Region. Index Copernicus Values 2016; 5(2): 611-5.

https://doi.org/10.21275/v5i2.NOV161226

19. Raikar SR, Kamdar PK, Dhabi AS. Clinical and laboratory evaluation of patients with fever with thrombocytopenia. Indian Journal of Clinical Practice 2013; 24(4):360-3.

20. Bhalara SK, Shah S, Goswami H. Clinical and aetiological profile of thrombocytopenia in adults. International Journal of Medical Science and Public Health 2015; 4(1):7-10. https://doi.org/10.5455/ijmsph.2015.06092 0141

21. Suresh P, Devi Y, Kumar C, Jalapa Y. Evaluation of the cause in fever with thrombocytopenia case. Journal of Evidence Based Medicine and Healthcare 2015; 2(15): 2134-7. https://doi.org/10.18410/jebmh/2015/326

22. Gandhi AA, AkholKar PJ. Clinical and laboratory evaluation of patients with febrile thrombocytopenia. National Journal of Medical Research 2015; 5(1):43-6.

23. Yaramis A, Yildrim I, Katar S, Ozbek MN, Yalcin I, Yalcin MA, et al. Clinical and laboratory presentation of typhoid Fever. International Journal of Clinical Pediatrics 2001; 16(4): 227-31. 
24. Sajid A, Ikram A, Ahmed M. Dengue fever outbreak 2011: clinical profile of children presenting at Madina teaching hospital Faisalabad. Journal of University Medical and Dental College 2012; 3(1):42-7.

25. Chitu $\mathrm{CH}$, Chandhra K. A clinical study of febrile thrombocytopenia: A hospital-based retrospective study. Indian Journal of Clinical Practice 2014; 24(12): 4549.

26. Nair PS, Jain T, Kanduri U, Kumar V. A study of fever associated thrombocytopenia. Journal of the Association of Physicians of India 2003; 51: 1151-73.

27. Saini KC, Agrawal RP, Kumar S, Tantia P, Thakkar K, Sharma AK. Clinical and aetiological profile of fever with thrombocytopenia - A tertiary care hospital based study. Journal of the Association of Physicians of India 2018; 66(4): 33-6.
28. Ayub M, Khazinder AM, Lubbad EH. Characteristics of dengue fever in a large public hospital, Jeddah, Saudi Arabia. Journal of Ayub Medical College Abottabad 2006; 18(2):9-13.

29. Palange PB, Kulkarni RB, Shrawasti RK. A study of clinical profile of patients with dengue fever with thrombocytopenia. International Journal of Recent Trends in Science and Technology 2015; 13(3): 671675.

30. Mohan K, Omar BJ, Singh RD, Aaradhana, Sachan R. Thrombocytopenia with bleeding manifestations in childhood malaria. Indian Journal of Child Health 2016; 3(3):196-200. 